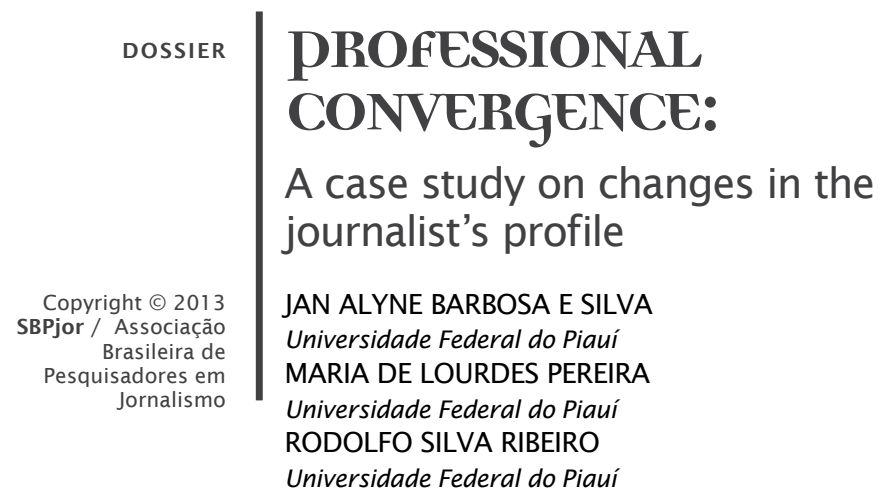

ABSTRACT - This paper aims at discussing some of the changes journalists have been going through, due to the use and appropriation of Communication and Information Technologies. This study is based on the case of Efrém Ribeiro, a journalist who works at Sistema Integrado de Comunicação Meio Norte, a TV broadcaster located in the city of Teresina, in the state of Piauí, Northeastern, Brazil. By exercising media and functional polyvalences, Efrém has been accumulating a number of functions previously distributed separately, as well as incorporating technological innovations in his production process. The case study consists of in-depth interviews and participant observation. The results show that the polyvalences occur only in terms of investigation and production of content for print, TV and the Web, however, deeply rooted in traditional, separate and divergent models and processes of production.

Keywords: Journalism. Polyvalence. Efrém Ribeiro.

\title{
CONVERGÊNCIA PROFISSIONAL: Estudo de caso das transformações no perfil do jornalista
}

RESUMO - O presente artigo tem por objetivo discutir algumas das transformações por que passam os profissionais em jornalismo, em função do uso e apropriação das Tecnologias de Informação e Comunicação, com base em um estudo de caso com o jornalista Efrém Ribeiro, do Sistema Integrado de Comunicação Meio Norte, na cidade de Teresina - PI. Exercendo as polivalências midiática e funcional, Efrém vem acumulando uma série de funções anteriormente distribuídas de forma segmentada e incorporando inovações tecnológicas aos seus processos produtivos. O estudo de caso é composto por entrevista em profundidade e observação participante. Verifica-se que as polivalências ocorrem apenas no plano da apuração e produção de conteúdos para o impresso, a TV e a Web, porém, arraigadas a processos e modelos produtivos tradicionais, separados e divergentes.

Palavras-chave: Jornalismo. Polivalência. Efrém Ribeiro.

\section{CONVERGENCIA PROFESIONAL: estudio de caso de las transformaciones en el perfil del periodista}

RESUMEN - Este artículo tiene como objetivo discutir algunas de las transformaciones por las que pasan los profesionales en periodismo, debido a la apropiación y uso de las Tecnologías de Información y Comunicación. Se utiliza para ello un estudio de caso con el periodista Efrém Ribeiro, del Sistema Integrado de Comunicación Medio Norte, ubicado en la ciudad de Teresina (estado brasileño de Piauí). Ejerciendo las polivalencias mediática y funcional, Efrém ha acumulado una serie de funciones previamente distribuidas de forma segmentada y ha incorporado innovaciones tecnológicas a sus procesos de producción. El estudio de caso consiste en entrevistas en profundidad y observación participante. Los resultados muestran que las polivalencias sólo ocurren en el plano de la apuración y producción de contenidos para los medios impresos; la televisión y la Red, sin embargo, continúan profundamente arraigadas en procesos y modelos de productivos tradicionales, separados y divergentes.

Palabras clave: Periodismo. Polivalencias. Efrém Ribeiro. 


\section{INTRODUCTION}

The recurrent transformations in media companies have largely met the demands of a market composed of producers and consumers. Convergence works in this context as a response to new communication processes emerged in the Information Technology and Communication (ICT), whereas affecting several dimensions which involve information production.

Along with changes in technology, which integrate processes and routines, as well as the restructuration of newsrooms, journalists face changes regarding their functional roles. One of the greatest expressions of this phenomenon is the imposition of incorporate functions previously performed by different journalists, demanding multiple skills to follow production processes in newsrooms.

As a profession weakened by several constraints, mainly regarding the monopoly of their activity and delimitation of functions in newsrooms, journalists and their working relationships are subject, without many options, to the pressures of competition from online media and to the discourse of constant updating. In this scenario, in order not to become obsolete, the journalist is compelled to develop new skills in terms of emerging practices, and according to each new technology created.

With cameras around his neck, audio recorder, notebook, smartphone, laptop and internet connection, the journalist Efrém Ribeiro, illustrates a behavior that gradually affects other journalists' productive routine within Sistema Integrado de Comunicação Meio Norte (SICMN), based in Teresina', which includes, besides the printed newspaper, radio and television broadcasts ${ }^{2}$ as well as an internet portal.

A journalist profile reproduces most of the practices which emerge in Brazilian news market, concerning the working hours, the amount of content they produce, the different media attended and the functions performed (KISCHINHEVSKY, 2009).

By producing news for newspaper, TV, news portal and blog, Efrém stands out when incorporating technological innovations to his productive routine, which often causes interference in the journalistic activities of other professionals at the company.

This professional aspect regarding convergence is one of the most controversial one because it exposes the weaknesses of training journalists to pursue those tasks at the same time, as well as the quality of equipment. Kischinhevsky (2009) also points out the system of labor 
relationship precariousness as well as the weakening of the analytical practice when building content.

The case study on the journalist Efrém Ribeiro consists of indepth interviews as well as participant observation, allowing us to set a comparative framework of a profile from a multitasking professional, not only regarding the many roles he performs in journalism, but also regarding the media and platforms he works for.

These kinds of polyvalence is part of what Salaverría and Negredo (2008) call professional dimension of convergence. The functional polyvalence occurs when Efrém Ribeiro performs several roles: he collects information, takes photos and edits the stories, although those have not necessarily been designed according to the specificities of each media or platform. At the same time, he works for different media linked to the Group, which can be characterized as media polyvalence.

It is important to highlight that, despite illustrating and helping to understand certain aspects of the profile of a contemporary journalist, this study, similar to many ethnographic studies, shows some difficulties regarding the generalization of results, since its conclusions are derived from a single case.

\section{PROFESSIONALIZATION AND CONSTRAINTS IN THE JOURNALISTIC MARKET}

The first attempts to frame journalism as a profession coincide with the beginning of some discussions about the sociology of professions in the nineteenth century, under transformations driven by industrialization of developed countries, especially Britain in Europe and the United States of America. Professionalization comes to ensure the monopoly of occupations due to high competition in the working field. In this same context, unions, associations, professional registration and the creation of university courses emerge (NEVEU, 2006).

According to Soloski (1993), in order for the profession to exist, it is necessary to have assured control over the cognitive basis of occupation, establishing a monopoly on the professional market. This monopoly is accepted due to a strong ideal of social character. It is acquired through formal education, providing not only standards, but also professional and ethical procedures to the workers, all of them are legally supported and accredited by the State. Otherwise, the legitimacy of services and employed methods would be questioned. Thus, it is 
required: 1) that a set of esoteric and sufficiently stable knowledge related to occupational task is taught by all professionals, and 2) that the public accepts the professionals as being the only ones who are able to provide professional services (SOLOSKI , 1993).

According to this author, the attempts to define the profession had the historical rise of medicine and law as a parameter, as they were older and less dependent on the market, when compared to other professions, which were directly aligned with business objectives of profitable scope, such as engineering, accountancy or journalism. However, for Soloski, there is an inadequacy in this model, since it is based on medicine and law models which are the ideology of professionalism, a manifested ideal in the notion of service to society with non-profitable components. However, the notion of professionalism, which is based on the monopoly of the occupation in professional market, is closely linked to a capitalist activity.

The capitalist force in journalistic activity has been reflected in the constant presence of the market, which is supported by the media, to promote their products, to increase the number of consumers and, above all, to have political bargaining power - although not associated to political engagement.

In this perspective, the need to ensure support from advertising revenues, and to increase the audience to compete with other companies has driven the media to turn to all types of audiences, making them adopt different characteristics in relation to the structure of the news, such as the adoption of the lead or the inverted pyramid, and business organizations, including the division of functions in newsrooms, as well as editorial choices.

These adaptations to the demands of media companies, consequently, have shaped a professional type for the journalists and their practices. According to Neveu (2006), journalistic practices of field reporting, data and information collection, and especially, the ideal of objectivity, one of the fundamental tools for ideological legitimation of journalism professionalization, were all born in the United States.

In the news market, two factors interfere in the profile of organizations and their relationship with professionals. The first one is related to the definition of the profession, since the criteria for professional recognition have not been taken literally. The second one involves projects of media companies, making the journalist susceptible to constraints of every order due to the scarcity of jobs (KISCHINHEVSKY, 2009). 
In many countries, official permission to practice journalism nowadays requires neither specific level of training nor even a degree in journalism. This situation stimulates competition from non-journalists, putting their independence at stake, besides favoring the weakening of the professional community in the struggle for valorization of the class with better payment plans and fringe benefits (NEVEU, 2006).

The constraints, however, do not only concern the core of organizations and the sorting of stories to be published. The profession is also subject to other field weaknesses, ranging from failures in journalism framework, definition of the profession, to external pressures from other professionals regarding the production of information, as well as the limits of attributions.

Moreover, the fragile consolidation of professionalization, and the strong interference of the market around the profitability in news organizations have offered little stability to professionals over the years.

\begin{abstract}
Young professionals have encountered a completely different market due to brutal modernization business processes, carried out from the second half of the 1980s on. Until the late 1970s, the newsrooms of major national press had been populated by hundreds of journalists, who had a typewriter as a maximum expression of their tools. [...] From that period on, the automation of processes in printing plants and, shortly thereafter, the computerization of newsrooms, have led to substantial changes in production routines of the press. It was the newspaper-company seeking production flexibility, characteristic of post-Fordism, against a backdrop of intense media forms segmentations. [...] Stages of manufacturing process have been compressed and eventually suppressed, causing cuts of costs with personnel and equipment and, by extension, financial gains for employers. The typewriter left the scene, being replaced by computers, and those who resisted the changes would invariably lose their jobs. Functions [...] have become extinct over the 1980s, and thousands of professionals have failed in returning... (KISCHINHEVSKY, 2009, p. 60-61).
\end{abstract}

In recent decades, Internet development, and the improvement of Information and Communication Technologies (ICTs) - which expanded access to production, circulation and fast consumption of information to anyone who knows how to write, shoot, take a picture and post it on the net - has caused great impact on this market. Accordingly, the increasing competition concerning content production, and migration of advertising to online environment - not always connected to journalism - were just some of the factors that pushed companies towards restructuring their newsrooms and reformulating journalistic products from the perspective of convergence as a way to suit the trends of modernization.

Above all, a greater impact has been observed concerning the journalist role demanded by the market which, in consequence, has 
caused many changes in the profession profile itself. Paradoxically, the lack of precise boundaries regarding the way journalism works, and the roles played by journalists in newsrooms can also be considered positive and softening factors amid the rapid changes which came along with the internet advent. In this sense, Neveu (2006, p. 40) affirms:

\begin{abstract}
Specifically for the journalist the conduct in relation to the boundaries, was based on enclosing new activities linked to the new media (radio, TV, Internet) over time. This amount of unprecedented work came to comfort the group. The absence of specific diploma requirement allowed the profession to integrate a variety of skills which contributed to its effectiveness.
\end{abstract}

Even in the countries where a diploma is required, several functions missing in the curricula - which do not follow the rapid update of the market - are incorporated by professionals in newsrooms, generating new productive processes. To Kischinhevsky (2009), in the last two decades of restructuring of media groups, stimulated by ICT, professionals have been crossed by convergence processes based on economic, social, political and cultural transformations. "In this new professional reality, the reporter should no longer be specialized in only one area of coverage for certain media, but rather be ready to communicate his or her collected information through several formats and languages" (KISCHINHEVSKY, 2009, p. 58).

\title{
POLYVALENCES AND TECHNOLOGICAL APPROPRIATION AS A WAY TO MEET DEMANDS OF CONTEMPORARY MARKET
}

Convergence is a polysemic term, and it can be studied from several points of view. The term had been applied as a concept announced in 1980 by the political scientist Ithiel de Sola Pool, and since then, it has been used to refer to a variety of concepts related to technological transformation of communication. According to Javier Noci (2011), before being associated with journalism, the concept of convergence had been employed in different fields such as mathematics, economics and biology.

Regarding convergence in media companies, it is permeated by the adoption of various models and strategies, depending on the culture and characteristics of each informative company of the communication group (BARBOSA, 2009; SALAVERRÍA e NEGREDO, 2008; KISCHINHEVSKY, 2009). 
The phenomenon of convergence also implies social and technological appropriation of tools, systems, devices and platforms, manifested by increasingly complex interactions between new and old media in unpredictable ways. In other words, the phenomenon involves the incorporation of new functions, new models of production, circulation, distribution and consumption of content, business models, removing professionals, businessmen and academics from their comfort zones and making imprecise boundaries between media, informational genres, public and practices (JENKINS, 2008).

According to Salaverría and Negredo (2008, p. 45), convergence is a process which promotes

[...] an integration of previously disaggregated tools, spaces, working methods and languages, so that journalists create content which are distributed across multiple platforms according to their own languages.

Regarding technological dimension of convergence, the focus concerns technological possibilities linked to production processes in newsrooms and the demands of a public increasingly interested by new media (SALAVERRÍA and NEGREDO, 2008).

The conduct of case studies based on in-depth interviews and participant observation helps to understand how technological dimension has been linked to professional dimension of convergence (SALAVERRÍA and NEGREDO, 2008). This dimension is concerned over the emergence of new professional profiles and production processes, such as the community manager, data journalist and multimedia journalist (BRADSHAW, 2013), in which journalist can perform various roles and media versatility, that is, the professional works for several informational products, which belong to a certain media business group (SALAVERRÍA and NEGREDO, 2008).

The need to train/enable polyvalent professionals has not been a consensus among scholars. Palacios, for instance, when giving an interview to Rost and Liuzzi (2012, p 18-19), compares the work performed in a converged newsroom as an orchestra, in which each musician plays his or her role:

\footnotetext{
You cannot train multitasking journalists without knowing the necessity for specialized platforms and specialized experts. When I think about convergence, I think about an orchestra: an orchestra converges and produces music, which is produced by different instruments. But each one is an expert in that instrument. Who plays the flute, does not play the tuba. Who plays the violin does not play the guitar ${ }^{3}$. (Translated by us)
} 
The reconfiguration of professional profiles has also been discussed due to the development and expansion of digital products of journalism, as these, according Mielniczuk and Marques (2007), are directly tied to the contexts of systemic production, and depend on the production models.

In this sense, we may see prospects for several practices of production, distribution, circulation and consumption of a flow of content through various media, languages, platforms and devices, applied to journalism, enabling the emergence and reconfiguration of professional roles (BRADSHAW, 2013; SALAVERRÍA and NEGREDO, 2008) as well as digital skills which reflect such practices and production models (NETWORK ICOD, 2006; FERRÉS and PISCITELLI, 2012).

The development of media skills must be, therefore, subject to a number of dimensions (languages, technologies, interaction processes, production and distribution processes, ideology and values, as well as aesthetics) indicators (scope of analysis or reception and scope of expression or production), as systematized by Ferrés and Piscitelli (2012). It is in this sense, among others, that we should rethink a curriculum for the field of Communication and Journalism in the Twenty-first Century (BURDICK et al, 2012).

\section{THE CASE OF POLYVALENCES PERFORMED BY EFRÉM RIBEIRO}

With the integration of Sistema Integrado de Comunicação Meio Norte (SICMN), new procedures have been introduced to the journalists' production routines. Among them, the use of online sharing platforms to search for sources, data and information collection and content publication. Mobile devices, such as laptops, smartphones, tablets and cameras, have been eventually incorporated into the day-to-day practices as the supporting of events coverage.

In order to illustrate aspects of professional convergence in SICMN, this case study aims at identifying how Efrém Ribeiro, a journalist who works at Sistema Integrado de Comunicação Meio Norte, has been performing media and functional polyvalences, while accumulating several functions, traditional and previously distributed on a segment basis, and incorporating technological innovations to his productive processes $^{4}$. To understand how such practices have been reflected in journalistic production, we performed an unsystematic observation of published content broadcasted on TV, in print and on the web. 
Efrém works under a hybrid model of cross-media synergy described by García Avilés and Carvajal (2008), in which the media from the same economic group maintains cooperative ties in news production, whilst preserving its operational independence. The printed newspaper is the "home environment" in which the journalist is allocated, while collaborating with production of content for various platforms linked to the group, on which we shall discuss later.

Efrém has been working as a journalist for 31 years. He holds a BA in Philosophy and Theology, and worked for Diário do Povo newspaper in Piauí, Northeastern Brazil, during the 1980s. At that time, he also worked for O Dia, another Brazilian newspaper based in Teresina, Piauí. In the 1990s, he studied Journalism and was a correspondent in Manaus, state of Amazonia, Northern Brazil, for Folha de S. Paulo, another Brazilian newspaper. In Manaus, he had the opportunity, due to the proximity to Peru, to do a masters degree in Philosophy at a Peruvian university.

Efrém has achieved recognition throughout Piauí due to his folksy style and the way he deals with different contents, ranging from sensationalism to the coverage of more serious topics, such as politics, education and social issues. In journalistic media, his journalistic productivity is three times greater than the average production of other journalists with equivalent function. According to former editor, Carlos Augusto Rocha, "Efrém is the dream of every publisher. Who wouldn't be willing to have a reporter who arrives at the newsroom with seven accomplished stories, more than enough to close a newspaper section?" Efrém explains that he always seeks for a "good story", rather than issues based on editorial guidelines, being the editor's duty, in his or her turn, to be responsible for the material selection and distribution among the sections.

Currently, Efrém works as a reporter in Meio Norte printed newspaper. Besides the common traditional activities of every reporter - verification and news writing - Efrém takes photographs, runs a blog ${ }^{5}$, produces stories for the portal Meio Norte.com, participates in programs and makes live inserts for Meio Norte TV. He is also a correspondent for some Brazilian newspapers, such as: O Globo, O Globo Online and O Globo agency. In Folha de S. Paulo, he had been a corresponding editor, but he defends that the role of reporter allows him to better explore his potential. He works from Monday to Friday from 07 a.m. to 11 p.m. as well as Saturdays and Sundays. Because of his routine, the other professionals who work for the newspaper, such as drivers and 
photographers, refuse to accompany him on his schedules. He does not get paid for overtime work, although he believes that he is well paid.

In daily work, he carries a range of equipment: two cameras, one professional and one 3D camera for HD shooting, iPhone and mobile, an ordinary audio recorder, notebook and iPad with 3G. During his work of investigation, the journalist keeps at least a camera to take photographs and make videos at hand. These devices are used to record unexpected events that may appear, and do not allow the preparation of a more complex equipment, which enables the professional to eventually produce scoops.

Efrém became well known not only because of his print publications, but also because of his works on the internet and Meio Norte TV. His popular and easily accessible profile allowed him to collect an extensive list of sources, and that is his asset to accomplish stories and receive information that other journalists are not able to get, particularly in the suburbs of Teresina.

As for equipment, they had been gradually acquired by the journalist himself, who claims to have invested in the acquisition of equipment so as to stand out in the market and to be always ready to capture the best story. In this case, the possession of electronic devices allows him to record the facts, shoot exclusive interviews broadcast on TV, many of which are transmitted live on the internet through the use of apps, tablet or smartphone.

Efrém understands that each device has its function and should be used in a different situation, according to the necessity. When using the camera, the recorded content can be used for TV, and also become photo for the newspaper. Despite doing the work of cinematographer in those cases, the journalist does not edit the images, but rather sends the raw material for the TV editing staff. According to him, it is the journalist's initiative to record and forward the material to the TV, rather than being a requirement of the company.

Although his production is mostly associated to writing and photographic records, the journalist eventually works as a TV commentator, talking about everyday affairs in police programs, cityrelated problems, and issues or events linked to the judiciary. He has been investigating backstage political information of an important account in the Legislative Assembly, or the coverage of a conference called by Labor Attorney in Piauí, both occurring on one of the days of public audiences.

Efrém does not receive extra payment for the content he 
produces for different platforms belonging to Meio Norte Group. Upon believing that every journalist should accept such conditions, his speech reflects the observation that "by facing scarce job opportunities, the professionals tend to be subject to abusive situations, naturalizing them" (KISCHINHEVSKY, 2009, p. 66). Despite the widespread discourse about bad working conditions in newsrooms (KISCHINHEVSKY, 2009), Efrém considers the physical structure and material resources of the company he works for to be enough to perform his job.

According to what he has stated, Efrém feels comfortable working with several devices since he sees no other way to maintain himself in the market if not by working with some differential, which reflects Kischinhevsky's observation once again (2009, p 67.):

With a job market redesigned by new Information and
Communication Technologies (ICT) and the precariousness of
working conditions, the discourse of convergence inevitability, and
the need to invest in professionals with multiple skills gain ground.

Éfrem believes that he has developed certain skills to produce content for different platforms over the years. In O Globo (newspaper and internet), for instance, he receives remuneration for productivity, and in O Globo agency, he is paid for each photograph published and sold. So as to perform such tasks, he has received neither training nor has taken a course. In order to operate the equipment, he just reads the manuals. Perhaps for this reason, all of his devices operate in basic function. The way he works echoes with Kischinhevsky's statement (2009, p. 67), that "journalists that hold the slightest knowledge of software for audio and video editing and/or Web programming have been prioritized in selective processes more and more, due to the exempt in spending on training".

In relation to software, he basically uses text editors and a specific editing platform, in which he posts the text to the editor ${ }^{6}$. He also writes for the blog (see figure 1), but receives help from other professionals when writing for the portal ${ }^{7}$ for which he informs the facts by telephone. 
Figure 1. Home of the Blog Efrém Ribeiro - the layout and images with camera, notebook, iPad and cell show the identity of a multimedia professional

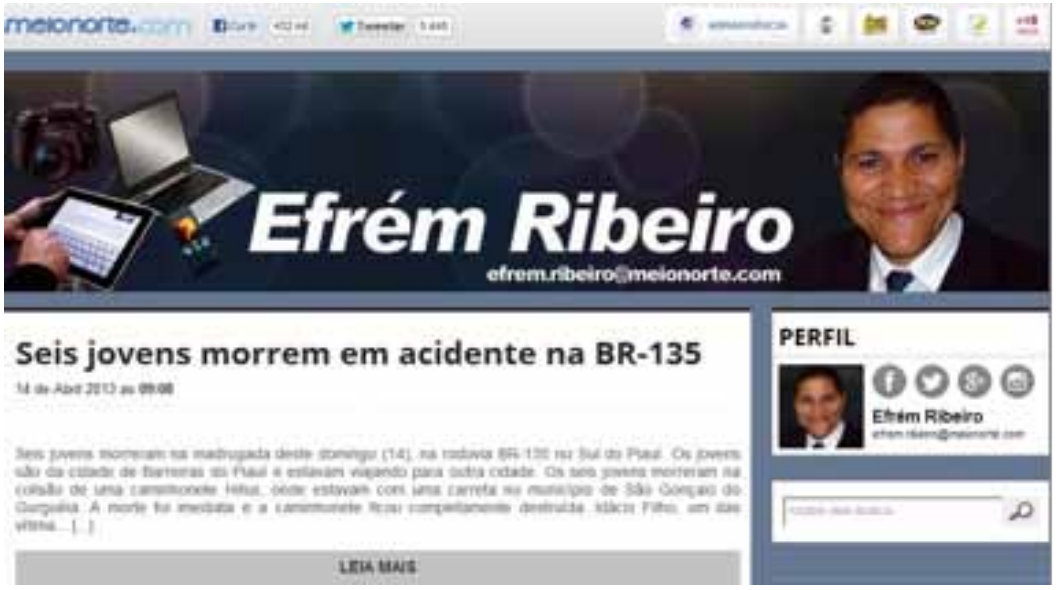

In media polyvalence, as explained by Salaverría and Negredo (2008), the journalist works for different news companies or media which belong to an organization (print, radio, TV etc.).

Regarding such aspect, Efrém feels comfortable with media versatility, that is, producing content for all platforms connected to Meio Norte group. However, he considers that his production is designed for printed media. His perception of convergence is reflected in the fact that the issue to be covered is always designed for the printed newspaper and if it gets more attention, it goes to the portal and TV. When he produces good images, the TV uses them. Efrém knows that TV channels need good images, and he has some knowledge about how they can be exploited. Therefore, the journalist admits having difficulties when operating some equipment, such as the camera, to ensure a good image that can be used on TV.

Although the newsroom of Meio Norte group is integrated, Efrém believes that there is little dialogue between journalists who work for different platforms belonging to the group, and that they are still identified according to the media for which they work. He also explains that there is a lot of competition among different media professionals connected to the group in general, as well as a natural competition on who produces the scoop. Often, professionals take advantage of what is produced for the different media, but sometimes they do not. It all depends on professional background. 
Thus, from an exploratory observation and semi-structured interviews, we can infer that despite performing media and functional polyvalences, production of content is not addressed to the specificities of support in terms of languages, and that much of his production is guided by the printed format.

This characteristic has its origins in the limitations of organizational and professional culture of the company. With regards to organizational limitations, the group has neither tools nor software to provide greater interaction between the newsrooms, and to support information production. Concerning the limitations of professional culture, the journalists have neither developed productive models in order to create and disseminate content according to the specificities of the platforms, nor a system to pre-plan investigation and writing, since everyone thinks the story from their sphere of production, that is, only for print or web or television.

\section{FINAL CONSIDERATIONS}

Efrém Ribeiro's perception reflects the management of a selfimage, and an identity of a multitasking professional who adapts to market demands. Despite being a professional with extensive experience in the market, Efrém Ribeiro does not seem resistant to change, since he claims to have attempted to adapt to new demands not only from the group he works for, but also from the market in general.

When performing differentiated roles, his situation resembles what Kischinhevsky (2009) observed in Editora O Dia. After beginning a partnership with the TV companies Rede Bandeirantes and Rede Record, two TV broadcasters in Brazil, the company started promoting its editors and reporters to submit stories or comments on TV from its newsroom. In the case of the newsrooms of Jornal do Brasil and Gazeta, the material produced by journalists was published both in print and on-line, without thinking on the specificities of each language, causing working overload to its professionals. O Globo in partnership with CBN radio from Belo Horizonte, would regularly receive flashes of news to be distributed to subscribers on on-line support, through either news agency or SMS.

This same process was experienced both by journalists from Tribuna do Norte and TN Online during the newsrooms integration process, and by professionals from Extra, according to the research of Maia and Agnez (2011). Professionals accumulate reports from the use of electronic devices, such as laptops and smartphones with internet 
access, as a support in news production, and also highlight the difficulties and pressures to adapt to the language and practices of different media for which they originally work (MAIA and AGNEZ, 2011).

This phenomenon, according to the researchers cited above, has happened in greater or lesser proportions in different newsrooms which opted for convergence as a market strategy. In Sistema Integrado Meio Norte de Comunicação, other professionals have also shared some practices of Efrém Ribeiro, as demonstrated in participant observation within the integrated newsroom. Journalists from different media, to greater or lesser extent, have gradually been incorporating new tasks and skills with digital devices and platforms.

This practice aims at meeting information demands emerging with new distribution channels of the media company, and $t$ is very encouraged by editors and administrators, such as the journalists of printed newspaper, who produce for the portal, run blogs and constantly participate on radio and television programs, thereby performing multiple roles and abilities outside their traditional media.

In this scenario, despite all the constraints, accumulation of functions, work overload and wage depreciation, the opinions on the process differ between having positive and negative effects on the professional, and the opinions also show a tendency to accept the need to adapt to emerging practices which are being developed in production routines from digital technologies.

From Efrém Ribeiro's point of view, except for low wages, and recognizing an inevitable need to adapt to market demands, his perception resembles the opinion of radio All News's journalists, based in Rio de Janeiro, systematized in the study undertaken by Kischinhevsky (2012, pp. 13-14):

If, on one hand, professional practice is seen as enjoyable and engaging for all respondents, on the other hand, the accumulation of functions, demands for increasing productivity and low wages contaminate the working environment, and cause resistance, whose main target are the increasing pressures for cost reduction, challenging the corporate strategy of integrating newsrooms.

Before such scenario, Masip et al. (2007) and Domingo et al. (2007) take the multifunctionality of a journalist as an excuse for staff cuts in newsrooms from several organizations. The excess number of tasks to be performed in a short time is the cause of many mistakes, since the priority is neither to accurately investigate nor to revise, but rather publish. 
In addition to that, there is not always a proper language or a media format through which content can be published, contrary to what Domingo et al. (2007) posit when emphasizing that the ideal multiskilled journalist should be able to produce content for any media, using technology in all phases of routine and production processes. According to the authors, journalists should also be able to adapt the stories to the languages of each media or support, developing the whole production process, besides having a certain resourcefulness in relation to the issues to be covered.

It appears that functional polyvalence occurs only in terms of investigation and producing content for print, TV and the Web, but always linked to traditional, separate and divergent production models and processes, since those contents are not necessarily designed according the specificities of each media or platform, as we have unsystematically observed in journalistic products for which the journalist works.

\section{NOTES}

1 The capital of the state of Piauí, located at the northeast of Brazil.

2 Meio Norte FM Radio and Boa FM Radio, Meio Norte TV and the portal www.meionorte.com.

3 In the original: No se puede formar periodistas multitask. Sigue habiendo la necesidad de la especialización por plataformas y especialización por temáticas. Cuando pienso en la convergencia pienso en una orquesta: una orquesta converge y produce una música que es producto de distintos instrumentos. Pero cada uno es un experto en ese instrumento. El que toca flauta, no toca tuba. El que toca violín no toca viola.

4 The case study includes participant observation and interviews with the journalist, conducted on March 02nd and 9th 2013, which allowed us to understand how those types of polyvalence happen.

5 http://www.meionorte.com/efremribeiro

6 The platform was developed to facilitate the work of editing and diagramming. The reporter enters text, lead, title and subtitle in separate spaces, and send for editing. The editor corrects and releases the text to the layout.

7 The newsroom of portal meionorte.com has seven journalists, a video editor and two web designers. As there is no external staff report, the journalists who work for the portal depend on the material produced by the teams of printed and television, which is edited and published in the on-line medium. 


\section{REERENCES}

BARBOSA, S. Convergência jornalística em curso: as iniciativas para integração de redações no Brasil. In: RODRIGUES, Carla (Org.). Jornalismo On-line: modos de fazer. Rio de Janeiro: Ed. PUC-Rio: Sulina, 2009. p. 35-55.

BRADSHAW, P. Pieces. Stories and streams. Teaching collaborative journalism using peer based learning. Leanpub, 2013. Available at: <https:// leanpub.com/storiesandstreams>. Retrieved: 26 nov. 2013.

BURDICK, A. et al. Digital Humanities. Cambridge: Massachussets Institute of Technology, 2012.

DOMINGO, D. et al. Four Dimensions of Journalistic Convergence: A preliminary approach to current media trends at Spain. 8th International Symposium on Online Journalism. Austin, Texas (EEUU), 2007. Available at: $\quad<$ http://onlinejournalism.utexas.edu/2007/papers/Domingo.pdf>. Retrieved: 30 jun. 2013.

FERRÉS, J., PISICITELLI, A. La competencia mediática: Propuesta articulada de dimensiones e indicadores. Comunicar, no. 38, v. XIX, Revista Científica de Educomunicación, pp. 75-82

GARCÍA AVILÉS, J. A. CARVAJAL, M. Integrated and cross-media newsroom convergence: two models of multimedia news production - the cases of Novotécnica and La Verdad Multimedia in Spain. Convergence: The International Journal of Research into New media Technologies, Sage, v. 14, n. 2, p. 221-239, 2008.

JENKINS, H. Cultura da convergência. São Paulo: Aleph, 2008.

KISCHINHEVSKY, M. Convergência nas redações: mapeando os impactos do novo cenário midiático sobre o fazer jornalístico. In: RODRIGUES, C. (Org.). Jornalismo On-line: modos de fazer. Rio de Janeiro: Ed. PUC-Rio: Sulina, 2009. p.57-74.

Como jornalistas do rádio All News percebem a convergência. Trabalho apresentado no 100 Encontro Nacional de Pesquisadores em Jornalismo, na Pontifícia Universidade Católica do Paraná. Curitiba, Novembro de 2012.

MAIA, K. B. F; AGNEZ, L. F. A convergência digital na produção da notícia: dois modelos de integração entre o impresso e o digital. Anais do I Colóquio Internacional Mudanças Estruturais no Jornalismo. Brasília, 2011. Available at: www.mejor.com.br. Retrieved: 28 nov. 2013.

MASIP, P. et al. Journalist convergence in Spain: changing journalistic practices and new challenges. In: IAMCR Conference, Unesco: Paris, 2007.

MIELNICZUK, L.; MARQUES, I. L. Sistemas publicadores para webjornalismo: mapalink, um protótipo para produtos de terceira geração. In: MACHADO, E.; PALACIOS, M. (Orgs.). O Ensino do jornalismo em redes de alta velocidade: metodologias \& software. Salvador: EDUFBA, 2007, p. 141-158.

NEVEU, E. Sociologia do jornalismo. São Paulo: Loyola, 2006.

$\mathrm{NOCl}$, J. D. Online News: narrative, hypertext and interactivity. An Analysis of Internacional Media. 345f. Tese para concurso de Cátedra. - Departamento 
de Comunicação. Barcelona: Universitat Pompeu Fabra, 2011.

REDE ICOD. Comunicação digital: competências profissionais e desafios acadêmicos. Livro Verde, 2006.

ROST, A.; LIUZZI, A. Reorganización de redacciones y nuevos perfiles profesionales. In: ROST, A.; BERGERO, F. Periodismo en contexto de convergencias. Rio Negro: Publifadecs, 2012.

SALAVERRÍA, R.; NEGREDO, S. Periodismo Integrado. Convergencia de Medios y Reorganización de Redacciones. Barcelona: editorialSol90media, 2008.

SOLOSKI, J. O Jornalismo e o Profissionalismo: Alguns Constrangimentos ao Trabalho Jornalístico. In: TRAQUINA, N. (Org.). Jornalismo: Questões, Teorias e 'Estórias'. Lisboa: Vega Sage, 1993

Jan Alyne Barbosa e Silva is doctor on Communication at the Post Graduation on Communication from Universidade Federal do Piauí (UFPI). She is member of the research group 'Grupo de Jornalismo OnLine' (GJOL) from Universidade Federal da Bahia (UFBA). E-mail: janalyne@gmail.com

Maria de Lourdes Pereira is a master student on Communication at Universidade Federal do Piauí (UFPI) and a member of the research group 'Grupo de Jornalismo OnLine' (GJOL) from Universidade Federal da Bahia (UFBA). E-mail: E-mail: lourdespereira.pi@ hotmail.com

Rodolfo Silva Ribeiro is a master student on Communication at Universidade Federal do Piauí (UFPI) and a member of the research group 'Grupo de Jornalismo OnLine' (GJOL) from Universidade Federal da Bahia (UFBA). E-mail: rodolfo@ribeiro.jor. br

RECEIVED ON: 28/09/2013 | APPROVED ON: 10/12/2013 
PROfESSIONAL CONVERGENCE 